\title{
Development and Physiology of Teliospores
}

\author{
Kurt Mendgen \\ Fakultät fiur Biologie, Lehrstuhl Photopathologie, \\ Universität Konstanz, Konstanz, Federal Republic of Germany
}

I. Introduction

II. Morphology and Ontogeny of Teliospore and Basidiospore Formation

A. Teliospore Morphology and Ontogeny

B. Teliospore Germination and Basidiospore Formation

III. Physiology of Teliospores

A. Factors That Induce Teliospore Formation under Natural Conditions

B. Artificial Induction of Teliospore Germination

IV. Germination and Penetration of Basidiospores

V. Conclusions

References

\section{Introduction}

In moderate climates generally during autumn, the dikaryotic mycelium that forms uredia with urediospores /see Harder, Chapter 11, this volumel begins to differentiate the overwintering spore form of the rusts, the teliospores. Teliospores were first described as fungal spores by the Tulasne brothers (Tulasne and Tulasne, 1847), who called them "perfect," or true spores. De Bary (1865) proposed for these true spores the term "Teleutosporen," because it means spores that appear at the end of the development of the species and may be applied to all homologous organs of rusts (". . Teleutosporen . . . bedeutet Sporen, welche am Ende der Entwicklung der Species auftreten und darum für die homologen Organe sämmtlicher Uredineen anwendbar sind"|. Later, Arthur (see Arthur, 1929, 1932) defined the term teliospore, because they are the spores that are formed in the telia, the last fruiting struc- 
ture of the rusts. More recently, teliospores have been defined as the basidia-producing spores of the rust fungi (Hiratsuka, 1973).

The teliospores are important for overwintering of most cereal rusts, and they are largely responsible for the formation of new physiologic races of the rusts (see Anikster and Wahl, 1979). Form and ornamentation of teliospores help to categorize the rusts. For a morphological description of the respective cereal rust teliospores, the reader is referred to the manuals of Cummins (1971), Gäumann (1959) and Urban (1969). The older, more general information on teliospores is summarized by Arthur (1929, 1934), Lehmann et al. (1937), Cummins (1959), and Hassebrauk (1962) in their descriptions of the different species. This chapter gathers more recent information on general characteristics of teliospores of cereal rust fungi. Where the information on important aspects is missing for cereal rusts, results from other rusts are included.

\section{Morphology and Ontogeny of Teliospore and Basidiospore Formation}

\section{A. TELIOSPORE MORPHOLOGY AND ONTOGENY}

Following urediospore production, teliospores are formed as a second type of spore in the uredium. The uredium is thus transformed into the telium or telial sorus. The telium may be open or covered by the epidermis of the host plant; see individual descriptions by Cummins (1971) or Gäumann (1959). The teliospores develop as pedicellate spores (Hughes, 1970; Harder, Chapter 11, this volume), which are produced from sporogenous cells (Fig. 1). The sporogenous cells are also responsible for urediospore formation (see Harder, Chapter 11, this volume). When a uredium has differentiated into a telium, the sporogenous cell of Puccinia coronata divides to form a remnant sporogenous cell (Figs. 1B and 2), a pedicel, and, in case of a telium, a primary teliospore cell (Harder, 1977). After nuclear division and subsequent development of a septum, the two-celled teliospore forms with two nuclei per cell (Fig. 1C,D). A heavy cap of wall material forms the crown at the terminal end of the outer cell (Fig. 3). Maturation of the teliospore is accompanied by an increase of cytoplasmic density, disappearance of vacuoles, and an accumulation of lipid droplets and glycogen-like material (Fig. 4). Densely staining secondary wall material forms, and a complex multilayered (as many as six layers) wall

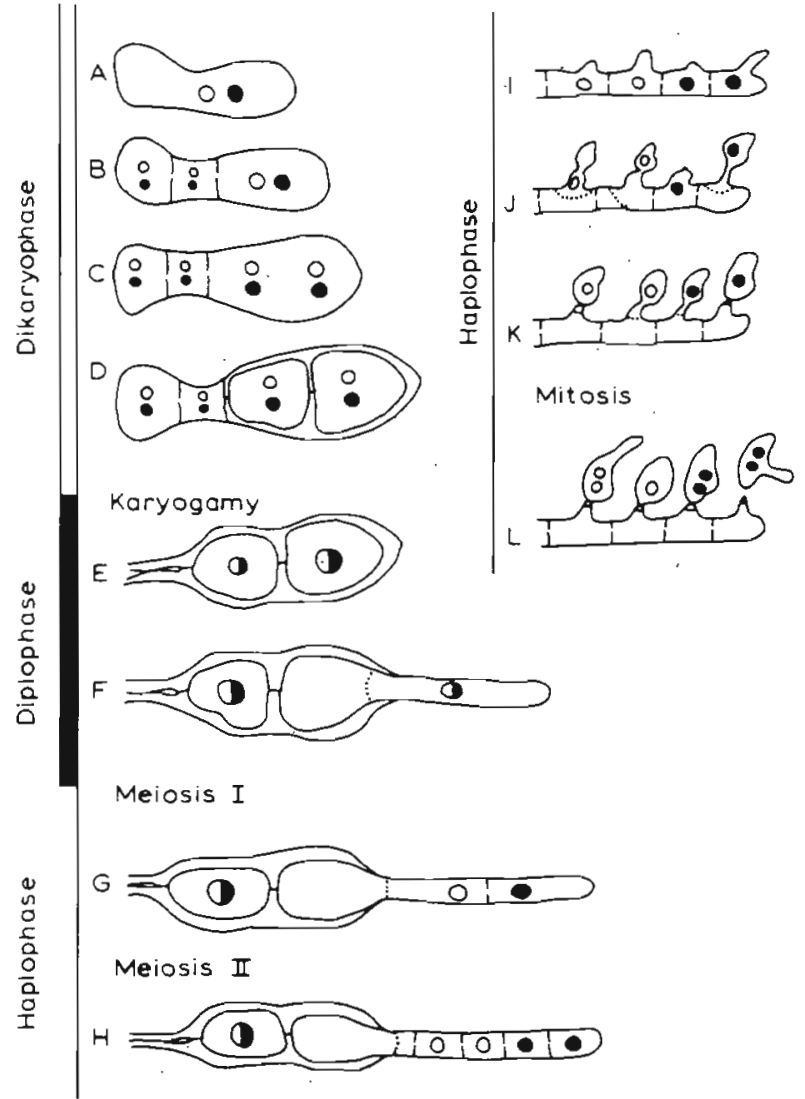

Fig. 1. Schematic sequence of teliospore and basidiospore formation. (A) Sporogenous cell. (B) Remnant sporogenous cell, pedicel, and primary teliospore cell. (C) Mitosis in the primary teliospore cell. (D) Septum formation results in the two-celled teliospore. (E) Nuclear fusion and maturation of the teliospore. (F) Germ tube emergence. (G) First meiotic division. (H) Second meiotic division. (I) Development of sterigma. (J) Vesicles with cytoplasm and nucleus develop at the end of the sterigma $|\mathrm{K}\rangle$ The basidiospores form. (L) Mitosis in the basidiospores and subsequent germination.

structure develops. Finally, the two nuclei within each cell become closely appressed and nuclear fusion occurs (Fig. 1E). The process of fusion has not been observed ultrastructurally, because fixation of spores appears to be very difficult at that stage (Harder, 1977). Sometimes nuclear fusion is delayed in teliospores of $P$. sorghi and may happen during overwintering (Pavgi, 1975).

Teliospore formation appears to be similar in the different rusts studied ultrastructurally, such as Uromyces appendiculatus (Müller et 

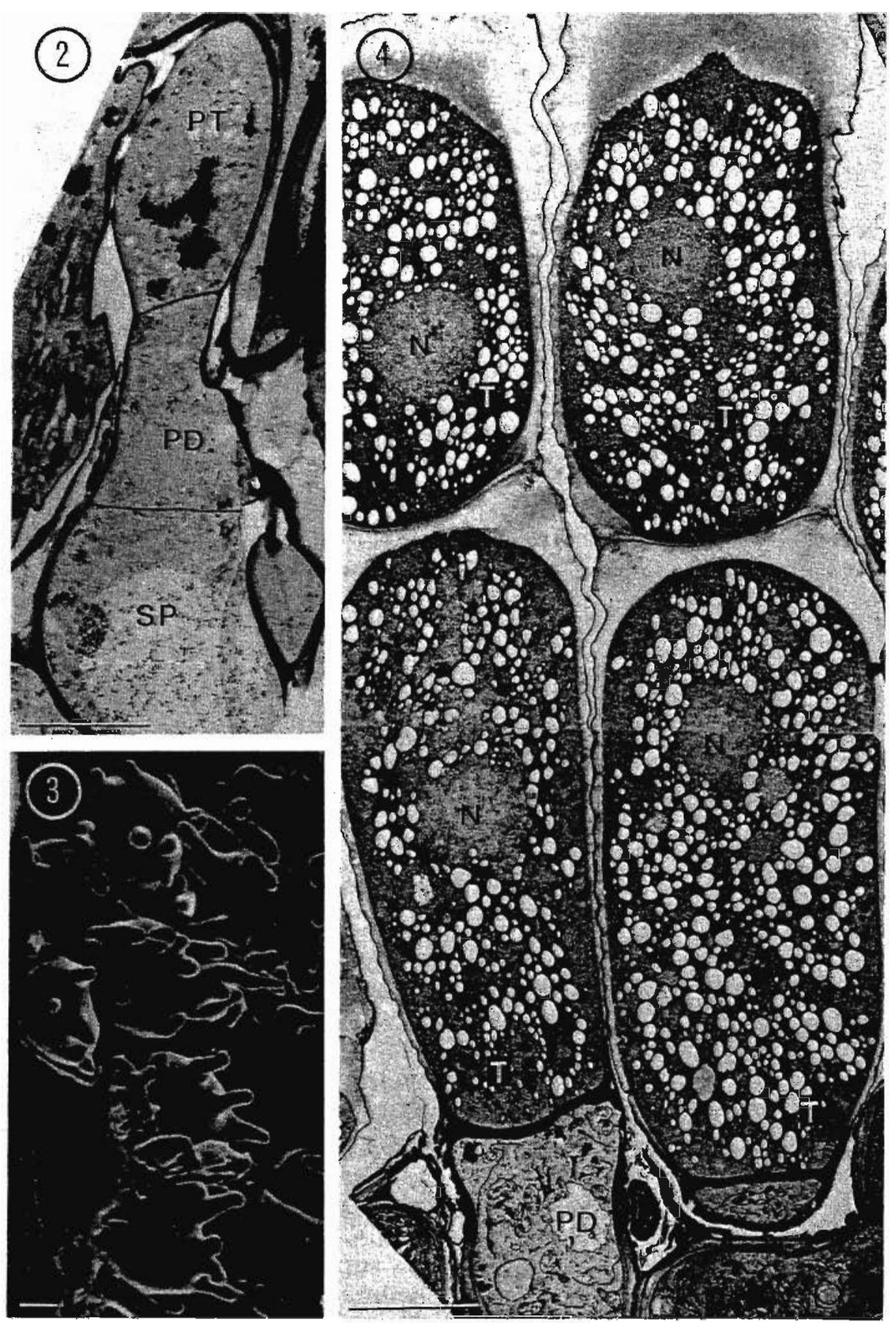

a1., 1974), Gymnosporangium iuniperi-virginianae (Mims et al., 1975; Mims, 1977b), P. podophylli (Mims and Thurston, 1979), P. smyrnii (Bennell et al., 1978), and Tranzschelia (Bennell and Henderson, 1978). The substructure of the spore wall is somewhat different, however: The results are difficult to interpret, because staining characteristics of the wall differ very much with spore age and fixation (Mims and Thurston, 1979; Rijkenberg, 1977|.

$P$. coronata has an apical or lateral germ pore that is indicated by a marked reduction in cell wall thickness (Harder, 1977). In P. sorghi, the wall becomes thickest at the apex of the spore, and a blunt, peglike projection of cytoplasm into the thickening apical wall marks the site of the germ pore (Riikenberg, 1977) (Fig. 5).

Teliospore ornamentation is extremely variable, and a classification of the ornaments based on electron microscopy is offered by von Brandenburger and Schwinn (1971) and Littlefield and Heath (1979). Wartlike ornaments of $P$. smyrnii appear initially, formed beneath the primary teliospore wall, and later are extruded to the surface of the spore (Bennell et al., 1978). The digitate processes that extend from the apex of $P$. coronata teliospores (Fig. 3 ) represent extensive wall thickenings (Harder, 1977). In P. podophylli (Mims and Thurston, 1979), the cytoplasm initially extends to the tip of the many thin-walled spines. Later, the cytoplasm disappears as a consequence of thickenings of the spore wall.

Most cereal rust teliospores have been described only by light microscopy (Cummins, 1971; Gäumann, 1959; Guyot, 1938, 1951, 1956; Ullrich, 1977; Urban, 1969). Morphology may be race-specific, as observed in P. sorghi (Pavgi, 1969), or differ after growth on different host grasses (Arthaud, 1969). Teliospores may be one- to five-celled (Kapooria, 1973) in $P$. penniseti. One-celled teliospores (mesospores) may comprise as much as $80 \%$ of the total found in P. hordei Otth. (Gäumann, 1959) and $2-17 \%$ of the total found in P. striiformis (Gäumann, 1959). In some isolates of $P$. hordei and $P$. recondita, $1 \%$ of teliospores may be three-celled (Y. Anikster, personal communica-

Fig. 2. Transmission electron micrograph (TEM) showing a sporogenous cell of Puc cinia coronata that has divided to form the primary teliospore cell (PT), the pedicel (PD), and the remnant sporogenous cell $(\mathrm{SP})(\times 3780$; bar, $5 \mu \mathrm{m})$ (courtesy D. E. Harder, Winnipeg). Fig. 3. Scanning electron micrograph (SEM) of surface view of a telial sonus, showing the cap or crown of teliospores of $P$. coronata. $(\times 1100$; bar, $5 \mu \mathrm{m})$. (From Takahashi and Furuta, 1973, with permission.) Fig. 4. Cross section of a mature teliosorus of $P$. coronata, showing the two teliospore cells $(\mathrm{T})$ and the adhering pedicel (PD). Nuclear fusion has occurred; $N$, nucleus (TEM, $\times 3700$; bar, $5 \mu \mathrm{m}$ ) (courtesy D. E. Harder, Winnipeg). 
tion). Even more variability is observed when teliospores of $P$. graminis are formed in artificial culture (Rajendren, 1972).

\section{B. TELIOSPORE GERMINATION AND BASIDIOSPORE} FORMATION

Teliospore germination and basidiospore formation have been reviewed by Gäumann (1926), Arthur (1929), Hassebrauk (1962), and more recently by Petersen (1974) and Littlefield and Heath (1979). The important aspects are described here, including results from $P$. sorghi (Pavgi, 1975 and work on noncereal rusts (Kohno et al., 1974, 1975, Mims, 1981; Mims et al., 1976; O'Donnell and McLaughlin, 1981a-d). In most cereal rusts, teliospores are dormant and germinate only after some months exposure to outdoor conditions (see next section). After hydration and before germ tube emergence, vesicles were observed in the cytoplasm of Uromyces phaseoli teliospores /Gold and Mendgen, 1981a). Fusion and reduction in size of lipid droplets, appearance of electron-translucent regions in the cytoplasm, and an enlargement of the fused nucleus were observed in Gymnosporangium clavipes (Mims, 1981). The pedicel of $P$. sorghi swells and disintegrates (Pavgi, 1975). In $G$. clavipes, the outer portion of the germ pore region disintegrates while the inner portion is pushed out and filled by the emerging germ tube (Mims, 1981). This germ tube or promycelium emerging from the teliospore is called a metabasidium, because meiosis occurs within this structure (for nomenclature, see Littlefield and Heath, 1979; Petersen, 1974; see also Wells and Wells, 1982I. In P. sorghi, the metabasidium grows out of the germ pore of the apical cell alone or of both cells simultaneously (Fig. 6). The germ tube wall appears to be continuous with an inner layer of the teliospore wall (Kohno et al., 1975; Mims et al., 1975; Mims, 1981). The entire protoplast usually migrates with the diploid nucleus into the metabasidium, and a septum is laid down at the base of the metabasidium in $P$. sorghi. Some: times, a portion of the cytoplasm remains behind in the spore. The

Fig. 5. Teliospore of $P$. sorghi showing nuclei with nucleoli $(\mathrm{n})$ and the germ pore (gp) of the upper teliospore cell. The lateral germ pore of the lower teliospore cell cannot be recognized $(\times 1400$; bar, $10 \mu \mathrm{m}$ ) (interference contrast, K. Mendgen, unpublished). Fig. 6. Germinated teliospore of $P$ sorghi with two metabasidia $(\mathrm{m})(\times 1000$; bar, $10 \mu \mathrm{m})$ (interference contrast, K. Mendgen, unpublished). Fig. 7. Metabasidium of $P$. sorghi. b,
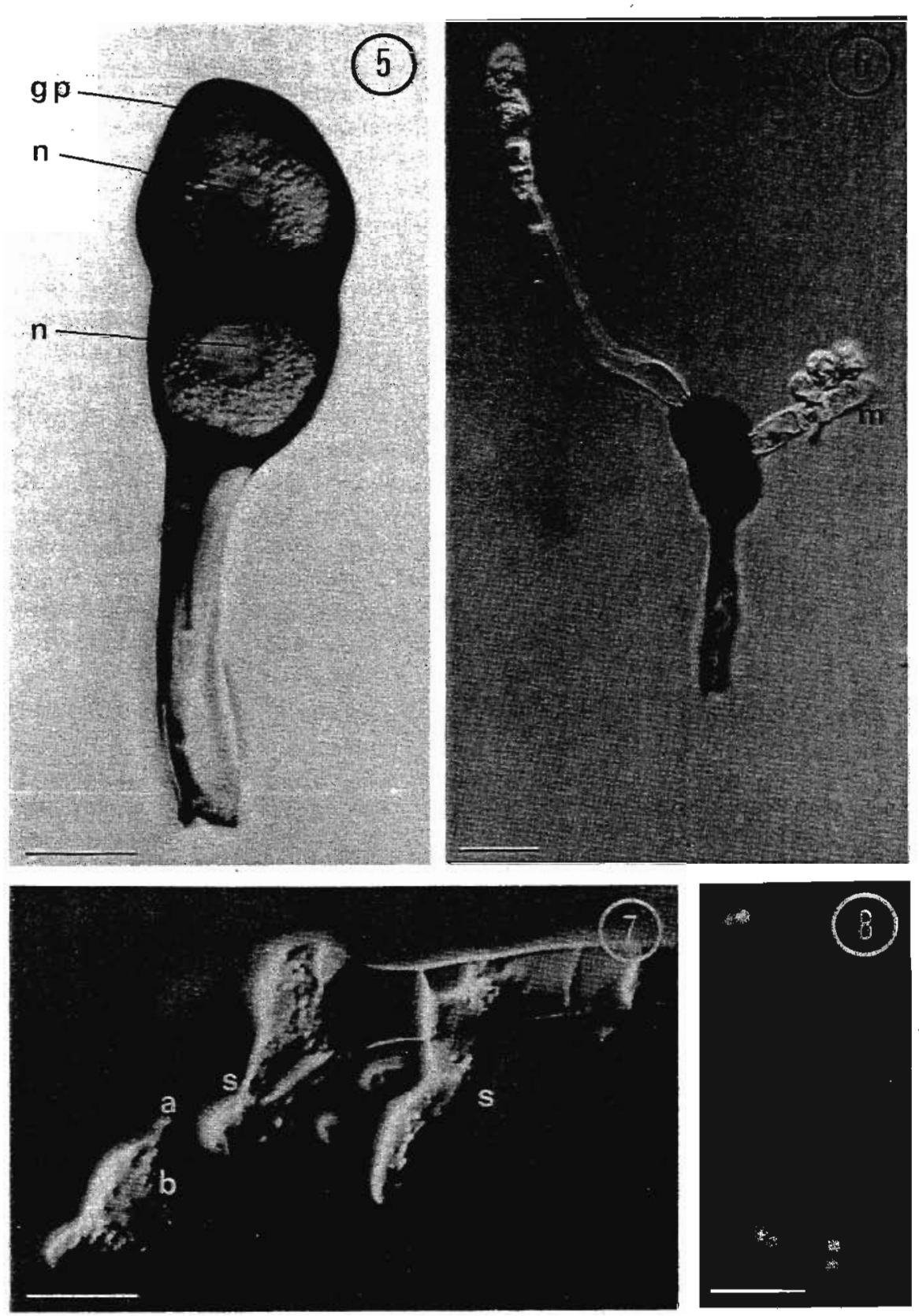

Basidiospore; a, apiculus; s, sterigmata. $(\times 1400$; bar, $10 \mu \mathrm{m})$ (interference contrast, $\mathrm{K}$ Mendgen, unpublished). Fig. 8. Basidiospores of $P$. hordei (host: Hordeum vulgare showing the two nuclei in each spore by fluorescence microscopy $(\sim \times 1200$; bar, $10 \mu \mathrm{m}$ (courtesy Y. Anikster, Tel Aviv). 
nucleus expands during interphase, and meiotic division proceeds rapidly under optimal moisture and aeration (Fig. IF-H).

A fine-structural study of the meiosis of cereal rusts is still missing. In Gymnosporangium, synaptonemal complexes, which indicate meiotic chromosome pairing ( prophase I), have been detected shortly after karyogamy, before the telial sorus is opened (Mims, 1977b, 1981). This would indicate that meiosis can begin before teliospores reach maturity and is then interrupted or delayed until teliospore germination. In $P$. malvacearum, a short-cycled rust, $\mathrm{O}^{\prime}$ Donnell and McLaughlin (1981a-d) observed the spindle pole bodies, responsible for spindle formation, when the metabasidium reached about $80 \%$ of its maximum length (Fig. 9). The fully developed spindle shows in Fig. 10 $(\sim$ metaphase I). The regrouping of the chromosomes at the cell poles shows in Fig. 11 ( telophase I). After this first nuclear division, called meiosis I, a septum forms between these two nuclei, and meiosis II proceeds (Fig. 12). Interestingly, the nuclei undergo a coordinated migration and rotation during meiosis. Differences in the development and form of the spindle pole body potentially provide important information on phylogenetic relationships among rusts (see O'Donnell and McLaughlin, 1981c).

The septa are formed centripetally and contain a narrow central pore with dense material (Fig. 13). After meiosis II and formation of another two septa, sterigma (Figs. II and 7) develop from small papillae. At the apex of the sterigma, a small vesicle with cytoplasm and nucleus emerges (Fig. 1J). The vesicles or basidiospores enlarge and are delicately supported by the sterigmatal ends (Figs. $1 \mathrm{~K}$ and 7). Sterigma and basidiospore formation resembles those in various basidiomycetes (Littlefield and Heath, 1979; Mims, 1981) and has been studied ultrastructurally for $G$. clavipes: The basidiospore is delimited from the sterigma by a septum at the base of the basidiospore and a septum in the neck of the sterigma (Mims, 1981).

The basidiospore in P. graminis is either uninucleate /Craigie and Green, 1962) or, after a subsequent mitotic division, binucleate. Examples for rusts with binucleate basidiospores are $P$. graminis f. sp. tritici, $P$. graminis f. sp. avenae, P. graminis f. sp. secalis, P. hordei (Fig. 8) $P$. recondita, $P$. striifòrmis (Y. Anikster, personal communication), $P$.

Fig. 9. Cross section through a metabasidium of $P$. malvacearum showing a nucleus during prophase I with a dispersing nucleolus (arrow) and an extranuclear, duplicated spindle pole body (double arrow) $(\times 4300 ;$ bar, $1 \mu \mathrm{m}$ ). (From ODonnell and McLaughlin, 1981a, with permission.) Fig. 10. A metabasidium of $P$. malvacearum with an oblique 1981 a, with permission.) Fig. 10. A metabasidium of $P$. malvacearum with an oblique
early-metaphase spindle during meiosis $I(\times 5500$; bar, $1 \mu \mathrm{m})$. (From O'Donnell and
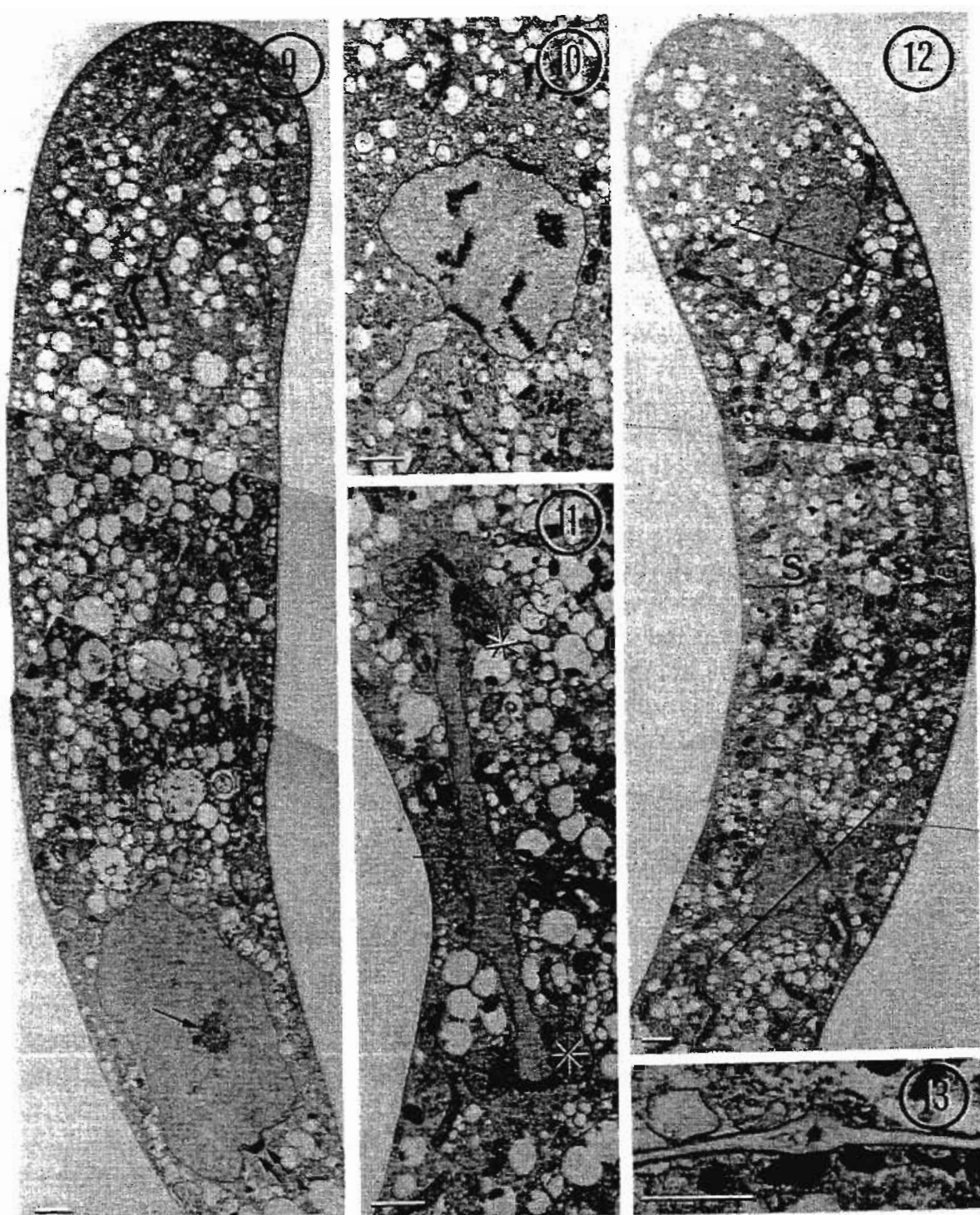

McLaughlin, 1981b, with permission.) Fig. 11. A metabasidium at late telophase during mat (a) (asterisks) ( $\times 6300$, bar, $1 \mathrm{um}$ ). (From O'Donnell and McLaughlin, 1981b, with permission.) Fig. 12. Early meiosis II (metaphase) showing nuclei with spindle axes (lines). The median septum (S) is still incomplete $(\times 3400$; bar, $1 \mu \mathrm{m})$. (From O'Donnell and McLaughlin, $198 \mathrm{lc}$, with permission.) Fig. 13. Median section through a septal pore of $P$. malvaceanmin at the end of meiosis II linterphase II containing electron-dense material and separated from the diaser McLaughlin, St. Paull. 
malvacearum (Allen, 1933), and many other rusts (Kapooria, 1968; Kulkarni, 1958; Pavgi, 1975; Mims, 1977a; Duncan and Galbraith, 1972; Kohno et al., 1977). In P. horiana, 31.5\% spores were tetranucleate (Kohno et al., 1974). There are conflicting reports on the number of chromosomes (three to five) in the different rusts (Kapooria, 1968, Pavgi et al., 1960).

In P. sorghi, many abnormalities from "normal" basidiospore formation in long-cycled rusts were observed by Pavgi (1975). Sometimes, inhibition of septum formation resulted in promycelial cells with two nuclei. From such abnormalities, a production of basidiospores with two compatible nuclei seems possible, and Pavgi (1975) suggests that they may produce aecia without the need of a transfer of spermatia from compatible pycnia, a conclusion also drawn from experiments with Uromyces spp. (Anikster et al., 1980). Thus both long- and shortcycled rusts can produce metabasidia with only two basidiospores, each containing nuclei of both mating types and therefore with the ability to produce aecia directly without first forming pycnia le.g., Uromyces viennot-bourgonii, U. christensii, U. hordeatri, Y. Anikster, personal communication).

\section{Physiology of Teliospores}

\section{A. FACTORS THAT INDUCE TELIOSPORE FORMATION}

UNDER NATURAL CONDITIONS

The teliospores of the macrocyclic cereal rusts are generally formed late in the season. The physiological background of teliospore formation remains obscure. Gassner and Franke (1938) cite many arguments against the assumption that the depletion of nutrients in older leaves induces teliospore formation. Benada (1966) tries to correlate the lower $\mathrm{pH}$ of the leaf sap with teliospore formation late in the season. However, teliospores are also produced by P. recondita on young plants (Jackson and Young, 1967). There are many examples showing that teliospore formation correlates with the cultivar-race combination used. Examples are $P$. recondita (Freitas, 1972; Waters, 1928; Takahashi et al., 1965; Jackson and Young, 1967), P. graminis f. sp. tritici, P. coronata (Rothman, 1974; Prasada, 1948; Sebesta and Bartos, 1966; Simons, 1954; Lisovii and Yabukova, 1973; Pillai et al., 1978; Hassebrauk, 1962; Takahashi et al., 1973; Zimmer and Schafer, 1960), and $P$. hordei (Joshi, 1965). An oat line that induces early formation of teliospores after inoculation by $P$. coronata does not show the same effect with $P$. graminis f. sp. avenae (Rothman, 1974). For such studies, contaminant-free telia of single physiologic race isolates of oat crown rust were obtained by injecting urediospores between the leaf sheath and culm at the base of each internode (Fleischmann, 19.64).

Early teliospore formation by cereal rusts can be induced by infection of rusted leaves with Cephalosporium acremonium (Hassebrauk, 1936) or with Aphanocladium album (Biali et al., 1972). This is also possible in leaf culture (Lesovoi et al., 1980) and axenic culture (Yaniv et al., 1979) of rusts. Extraction of A. album cultures with ethyl acetate or chloroform yielded an extract that reliably induced teliospore formation of P. graminis, P. sorghi, and P. dispersa (Forrer, 1977). A similar effect was observed after simultaneous infection of cereals with $P$. recondita f. sp. triticina and Septoria nodorum (Van der Wal, 1970).

\section{B. ARTIFICIAL INDUCTION OF TELIOSPORE} GERMINATION

Teliospores of $P$. heterospora germinate readily in less than $8 \mathrm{hr}$ at $26^{\circ}$ to $28^{\circ} \mathrm{C}$ without any resting period and remain viable for less than 10 days (Kotwal, 1970). Teliospores of $P$. graminis f. sp. tritici do not germinate readily and may remain viable at least 6 years under laboratory conditions (Johnson, 1941). Nearly all life durations in between have been reported (Lehmann et al., 1937). Most (Kühn, 1858; Tulasne and Tulasne, 1847) but not all (P. glumarum, Gäumann, 1959; P. purpurea, Prasada, 1948) teliospores of the cereal rusts are dormant. $P$. sorghi and $P$. graminis $\mathrm{f}$. sp. avenae are somewhat intermediate for nonuniform), in that some spores germinate at once, the others only after a period of some months (Godoy and Bruny, 1952; Hingorani, 1952; Neuhaus, 1966). For some rust fungi, such as P. glumarum |= striiformis), there are conflicting reports (Gäumann, 1959; Prasada, 1948). Following the definition of Allen (1965) and Sussman and Halvorson (1966), the dormancy of teliospores is constitutional, because it is an innate property of the spore that requires an activation process to be broken and is not a consequence of the presence of inhibitory environmental factors.

Several methods have been proposed to induce germination of dormant teliospores. In some cases, a prerequisite for any germination at all is that the teliospores be produced below $15^{\circ}$ to $18^{\circ} \mathrm{C}$ (Joshi, 1965; Hennessy and Sackston, 1970). It also should be noted that reports appear very often in conflict, and a method adequate for one rust spe- 
cies or race of a species may not work with others (Chin et al., 1965). A representative selection of methods recommended mainly for cereal rusts is presented here:

1. Storage of spores or leaves with telia (De Bary, 1863; Kühn, 1858) outside, under humid conditions (Eriksson and Henning, 1896, Klebahn, 1916; Lambert, 1929). Storage under dry conditions was very often unfavorable (Schilberszky, 1930; Ward, 1888).

2. Freezing and thawing the spores (Johnson, 1930; McAlpine, 1906)

3. Wetting and drying the spores (Dinoor, 1962; Hooker and Yarwood, 1966; Klebahn, 1914; Lumbroso et al., 1977)

4. Treatment of spores with X rays (Line, 1963) and heat (Gold and Mendgen, 1981a,b; Maneval, 1927)

5. Treatment of teliospores of $P$. graminis with citric acid (Thiel and Weiss, 1920), buffers (Maneval, 1927), and other acids (Sibilia, 1930); treatment of teliospores of P. carthami with volatile polyacetylenes from safflower (Binder et al., 1977; Klisiewicz, 1972, 1973 and treatment of $U$. appendiculatus teliospores with unknown volatile substances from bean (Gold and Mendgen, 1981b)

6. Keeping fresh spores on agar and waiting until they germinatesome always will (Groth and Mogen, 1978; Maneval, 1927)

7. Exposing spores to light regimens (Neuhaus, 1969)

Unfortunately, very few quantitative data exist, making it impossible to compare the different methods. Two ways might be recommended for a beginner: (1) storage outside under winter conditions and (2) washing fresh spores or pieces of rusted leaves with distilled water at $13^{\circ}$ to $16^{\circ} \mathrm{C}$ and transferring them onto $4 \%$ agar (with $40 \mathrm{ppm}$ chloramphenicol). Either method will induce at least some $(\sim 0.0001 \%)$ germination (Y. Anikster and I. Wahl, personal communication). With bean rust (U. appendiculatus), germination of teliospores was observed on water agar after outside storage during winter, freezing and thawing cycles of fresh spores, heat treatment of fresh-dried spores 5 or 10 days at $40^{\circ} \mathrm{C}$; R. E. Gold and K. Mendgen, unpublished), heat treatment of fresh spores on agar $\left(4\right.$ days at $\left.31.6^{\circ} \mathrm{C}\right)$, or treatment of fresh spores with volatile substances from bean germlings (Gold and Mendgen, 1981a,b). However, germination varied considerably with the bean rust isolate used.

To improve our understanding of teliospore dormancy, some quantitative data from Gold and Mendgen (1981b) on teliospore germination of $U$. appendiculatus var. appendiculatus $(=U$. phaseoli) are dèscribed here. If fresh teliospores are stored at $4^{\circ} \mathrm{C}$ in a refrigerator, and samples of these are tested periodically on agar at $18^{\circ} \mathrm{C}$, germination starts after a dormancy period of about 6 months (Fig. 14). This dormancy period can be interrupted with any of the methods previously described. With refrigerator-stored teliospores or after an activation such as with volatile substances from the host plant, we observed a preemergence lag of about 4 to 5 days at $18^{\circ} \mathrm{C}$ before the germ tube emerged (Fig. 15). The formation of the metabasidium with the basidiospores and basidiospore discharge takes only $4-6 \mathrm{hr}$ at $18^{\circ} \mathrm{C}(\mathrm{R} . \mathrm{E}$ Gold, personal communication). The data should not be generalized before other rusts are examined, because very few time course studies on teliospore germination have been performed (e.g., Spaulding and Rathbun-Gravatt, 1926). Dietel (1911, 1912b, 1915, 1921) reported that, depending on the resting period, teliospores of $P$. graminis take from 2.5 to $30 \mathrm{hr}$ before they germinate. Lambert (1929) mentions a preemergence lag of 3 days before teliospore germination of this fungus begins. A very broad temperature range for germination $\left(15^{\circ}-22^{\circ} \mathrm{C}\right)$ is also reported (Lehmann et al., 1937). Overwintered teliospores of $P$. sorghi begin to germinate at $17^{\circ} \mathrm{C}$ after $48 \mathrm{hr}$ on agar. After the preemergence lag, basidiospore formation is finished within the following 6 to $12 \mathrm{hr}$ at $17^{\circ} \mathrm{C} / \mathrm{K}$. Mendgen, unpublished). During the time of teliospore germination and basidiospore formation, high humidity

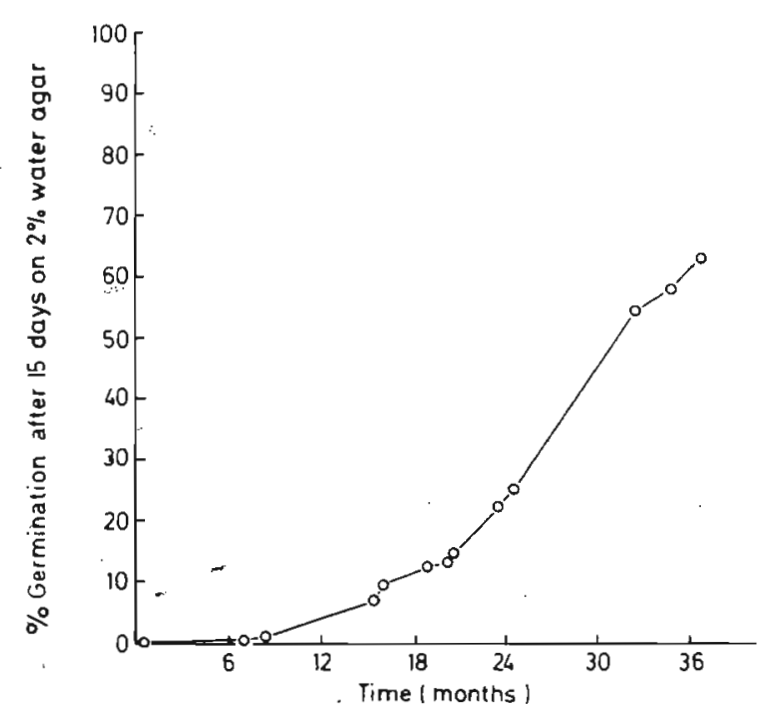

Fig. 14. Germination of samples of teliospores during a 3-year storage period at $4^{\circ} \mathrm{C}$. Uromyces appendiculatus var. appendiculatus, modified after Gold and Mendgen 1981b. 


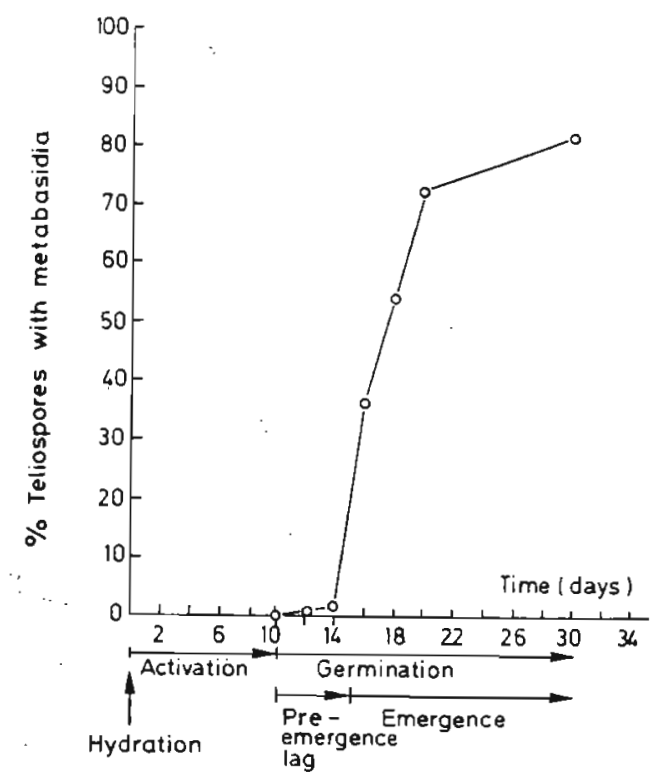

Fig. 15. Germination of fresh teliospores of Uromyces appenduculatus after activation with volatile substances from the host plant in a closed chamber and subsequent incubation on agar at $18^{\circ} \mathrm{C}$. The preemergence lag was also observed when 3-year-old teliospores were used, which germinate readily without activation. (Modified after Gold and Mendgen, 1981b.)

conditions are needed. However, teliospores should not be covered with water as observed for $P$. graminis (Blackman, 1903).

Teliospore germination is influenced by light regimes very often (Carter and Banyer, 1964; Pady and Kramer, 1971; Pearson et al., 1977; Van Arsdel, 1967). Teliospores of $U$. appendiculatus germinate and release their basidiospores $\sim 7 \pm 0.7 \mathrm{hr}$ after a light-off signal (Fig. 16) A daily exposure to $1000 \mathrm{lux}$ for $0.5 \mathrm{hr}$ was sufficient for the induction of the germination process. Thus under a day-night regimen, the teliospores have, after appropriate activation, the lag of about 4 to 5 days and then a rhythmic basidiospore discharge during the following 4 to 6 nights (Gold and Mendgen, 1981b; Gold and Mendgen, 1983a,b).In the cereal rusts, a recent study of light influence exists only for $P$. sorghi (Neuhaus, 1969). The teliospores of this rust needed only 1000 lux during $1 \mathrm{~min}$ for germination. Studies with P. graminis (Maneval, 1927; Lambert, 1929) did not find an influence of a day-night regimen. More studies are needed to elucidate this question in the cereal rusts. A mechanism that would explain constitutive dormancy is known neither for rusts nor for other fungi. Harder (1977) discusses wall

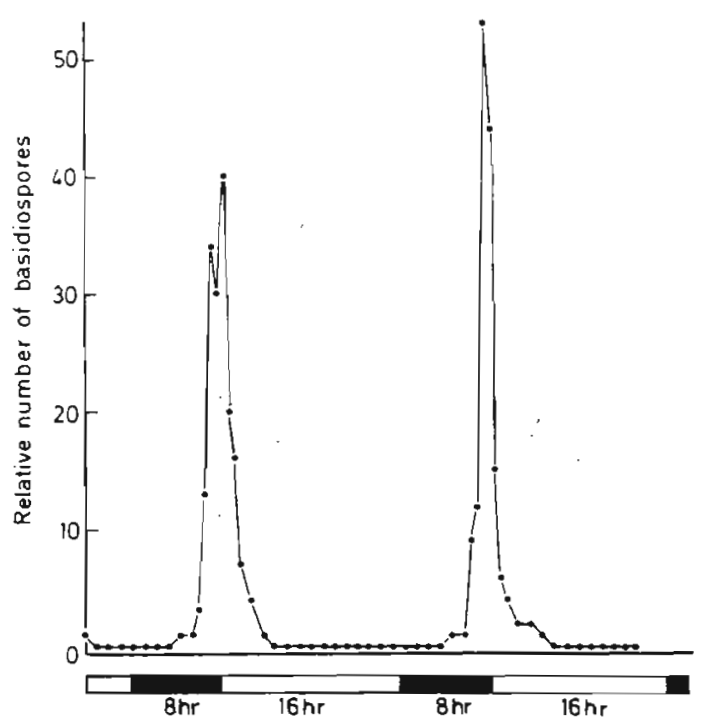

Fig. 16. Basidiospore discharge during a regimen of $8 \mathrm{hr}$ darkness (dark segment of bar and $16 \mathrm{hr}$ light (light segment of bar) $\left(1000\right.$ lux, $\left.18^{\circ} \mathrm{C}\right)$. The teliospores had been stored at $4^{\circ} \mathrm{C}$ for 2 years. Basidiospore discharge began in the fourth or fifth dark period during the indicated light regimen. (Modified after Gold and Mendgen, 1981b.)

qualities as one factor with respect to dormancy in the crown rust fungus. In other fungi with similar qualities, the roles of compartmentalization within the spore (Mandels, 1981), membrane features (see Turian and Hohl, 1981), and catalytic activities of mitochondria (Wenzler and Brambl, 1981) have been discussed.

\section{Germination and Penetration of Basidiospores}

The basidiospores of the rusts in general do not seem to have special morphological characteristics (Littlefield and Heath, 1979). Basidiospores of rusts (e.g., G. juniperi-virginianae, Mims, 1977a) have a prominent apiculus, an appendage by which the spore was attached to the sterigma (Fig. 7).-The basidiospores of different Puccinia species are catapulted from their sterigma as far as 0.6 to $1 \mathrm{~mm}$ (Y. Anikster, personal communication; Buller, 1924; Dietel, 1912a; Lambert, 1929). Dietel $(1912 \mathrm{a}, \mathrm{b})$ calculates from such measurements a catapulting speed of $8 \mathrm{~cm} / \mathrm{sec}$. Once airborne, the basidiospores may be transported by the wind at high air humidity over a distance of about $5 \mathrm{~m}$ 
(Yamada et al., 1973). Basidiospores germinate under such high-humidity conditions without delay (De Bary, 1865, 1866; Waterhouse, 1921), with a short, delicate germ tube. It may act as a sterigma by producing secondary basidiospores (De Bary, 1866) or lead to formation of an appressorium-like structure on the host leaf (De Bary, 1865, 1866; Waterhouse, 1921).

The basidiospores of P. graminis (Waterhouse, 1921) and G. fuscum (Metzler, 1982) need less then $20 \mathrm{hr}$ at $20^{\circ} \mathrm{C}$ to penetrate the epidermis.

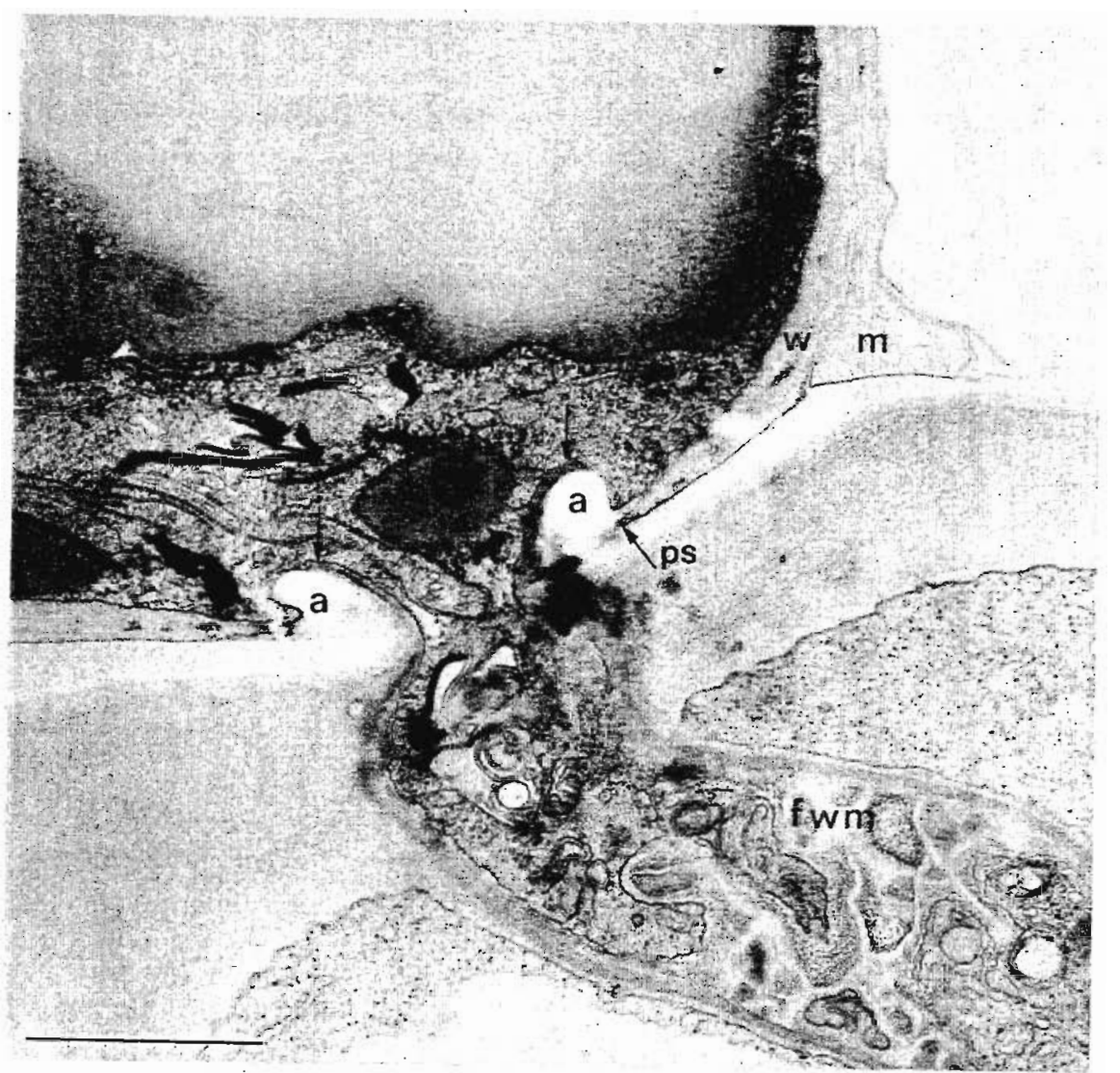

Fig. 17. Cross section at the penetration site through the basidiospore germ tube of Gymnosporangium fuscum on a pear leaf. The wall $(w)$ of the basidiospore germ tube (appressorium) is covered with mucilage $(\mathrm{m})$ and thins out at the penetration site (ps) new wall (arrows) is laid down around an "appressorial ring" (a) thus delimiting penetration peg. At this late stage of infection, the penetation peg is occluded with fungal wall mat A f fungal wall material (fwm). (TEM; $\times 25,520$; bar, $1 \mu \mathrm{m}$ ). (From Metzler, 1982, with
permission.)
During germination of Gymnosporangium, large lipid bodies can be observed in the cytoplasm that seem to be degraded gradually. Numerous vesicles are present in the spore near the germ tube and in the germ tube (Mims, 1977a). The germ tube and the appressorium of P. graminis basidiospores are covered with a mucilage layer (Waterhouse, 1921; Novotelnova, 1935). The germ tube wall formed by the basidiospore is continuous with a newly formed inner wall layer in the basidiospore.

The appressorium of $G$. fuscum formed on contact with the host is not separated by a septum from the germ tube (Metzler, 1982). As with $P$. graminis, the appressorium is surrounded by a mucilage that may stick to the host surface (Fig. 17). The appressorium wall thins out at the penetration site and differentiates an inner ring (appressorial ring) before penetration of the host cell (Fig. 17). The function of the appressorial ring is still unknown. The penetration peg itself is formed by a new inner wall layer near the appressorial ring (Metzler, 1982) and is not continuous with the appressorial wall. After successful penetration, the penetration peg is occluded by fungal wall material (Fig. 17). This wall material seems to separate the protoplast in the growing hyphae from the empty appressorium outside on the epidermis. For $P$. graminis, only a light microscope description of the infection process by basidiospores exists (Waterhouse, 1921). Melander and Craigie (1927) observed that the progressive increase in resistance of very young to old leaves of Berberis vulgaris to basidiospore infection of $P$. graminis is positively correlated with increased thickness of the cuti. cle of epidermal cells and increased resistance to mechanical puncture However, physiological reasons for differences in susceptibility have not been excluded.

The intercellular and intracellular structures subsequently formed by the monokaryotic rust fungus are described by Harder in Chapter 11 of this volume.

\section{Conclusions}

After their first description by Tulasne and Tulasne (1847), the teliospores of the rust fungi have been studied in many details. Most articles deal 'with teliospore morphology and infectivity of basidiospores (Cummins, 1971; Gäumann, 1959; Hassebrauk, 1962). Some describe the metabasidium and basidiospore formation. Ultrastructural studies are restricted to very few rust species, mainly $P$. mal- 
vacearum and Gymnosporangium spp. There is a lack of ultrastructural studies on the cereal rust teliospores, their germination, and the basidiospore infection process. Studies on the physiology of teliospore dormancy and teliospore germination are still only beginning. Experiments with the cereal rusts similar to the studies on other rusts as described in this chapter are urgently needed, because teliospore be havior plays an important role in the perpetuation of the disease from one season to the next.

\section{Acknowledgment}

I thank Y. Anikster, W. R. Bushnell, and D. J. McLaughlin for reviewing the manuscript.

\section{References}

Allen, P. J. (1965). Metabolic aspects of spore germination in fungi. Annu. Rev. Phytopathol. 3, 313-342.

Allen, R. F. (1933). A cytological study of the teliospores, promycelia, and sporidia in Puccinia malvacearum. Phytopathology 23, 572-586.

Anikster, Y., and Wahl, I. (1979). Coevolution of the rust fungi on Gramineae and Liliaceae and their hosts. Annu. Rev. Phytopathol. 17, 367-403.

Anikster, Y., Moseman, J. G., and Wahl, I. (1980). Development of basidia and basidiospores in Uromyces species on wild barley and Liliaceae in Israel. Trans. Br. Mycol. Soc. 75, 377-382.

Arthaud, J. (1969). Contribution à l'étude des anomalies sporales chez le Puccinia graminis. C. R. Hebd. Seances Acad. Sci., Ser. D 268, 1502-1504.

Arthur, J. C. (1929). "The Plant Rusts (Uredinales)." Wiley, New York.

Arthur, J. C. (1932). Terminologie der Uredinales. Ber. Dtsch. Bot. Ges., 50A, 24-27.

Arthur, I. C. (1934). "Manual of the Rusts in United States and Canada"" Purdue Res. Found., Lafayette, Indiana.

Benada, J. (1966). The accurrence of telia of rusts and of cleistothecia of powdery mildew on cereals and an attempt to find a factor conditioning it. Zentralbl. Bakteriol Parasitenkd., Infektionskr. Hyg., Abt. 2, Naturwiss.: Allg., Landwirtsch. Tech. Mikrobiol. 120, 427-433.

Bennell, A. P., and Henderson, D. M. (1978). Urediniospore and teliospore development in Tranzschelia (Uredinales). Trans. Br. Mycol. Soc. 71, 271-278.

Bennell, A. P., Henderson, D. M., and Prentice, H. T. (1978). The teliospores of Puccinia smymii (Uredinales). Grana Palynol. 17, 17-27.

Biali, M., Dinoor, A., Eshed, N., and Kenneth, R. (1972). Aphanocladium album, a fungus inducing teliospore production in rusts. Ann. Appl. Biol. 72, 37-42.

Binder, R. G., Klisiewicz, J. M., and Waiss, A. C., Ir. (1977). Stimulation of germination of
Puccinia carthami teliospores by polyacetylenes from safflower. Phytopathology 67, $472-474$.

Blackman, V. H. (1903). On the conditions of teleutospore germination and of sporidia formation in the Uredineae. New Phytol. 2, 10-14.

Buller, A. H. R. (1924). "Researches on Fungi," Vol. II. Longmans, Green, New York

Carter, M. V., and Banyer, R. J. (1964). Periodicity of basidiospore release in Puccinia malvacearum. Aust. J. Biol. Sci. 17, 801-802.

Chin, K. J., Chang, K. C., and Hsuen, L. H. (1965). On the teliospore germination of Puccinia graminis var. tritici. Acta Phytophylacica Sin. 4, 201-206.

Craigie, J. H., and Green, G. J. \{1962\}. Nuclear behavior leading to conjugate association in haploid infections of Puccinia graminis. Can. J. Bot. 40, 163-178.

Cummins, G. B. (1959). "Illustrated Genera of Rust Fungi." Burgess, Minneapolis, Minnesota.

Cummins, G. B. (1971). "The Rust Fungi of Cereals, Grasses and Bamboos." SpringerVerlag, Berlin and New York.

De Bary, A. (1863). Recherches sur le développement de quelches champignons parasites. Ann. Sci. Nat., Bot. Biol. Veg. [4/ 20, 5-148.

De Bary, A. \{1865\}. Neue Untersuchungen über die Uredineen, insbesondere die Entwicklung der Puccinia graminis und den Zusammenhang derselben mit Aecidium berberidis. Monatsber. K. Preuss. Akad. Wiss. Berlin pp. 15-50.

De Bary, A. (1866). Neue Untersuchungen über Uredirieen. Monatsber. K. Preuss. Akad. Berlin Wiss. pp. 205-215.

Dietel, P. (1911). Versuche über die Keimungsbedingungen der Teleutosporen einiger Uredineen. I. Zentralbl. Bakteriol., Parasitenkd., Infektionskr. Hyg., Abt. 2, Naturwiss.: Allg., Landwirtsch. Tech. Mikrobiol. 31, 95-106.

Dietel, P. (1912a). Über die Abschleuderung der Sporidien bei den Uredineen. Mycol. Centralbl. 1, 355-359.

Dietel, P. (1912b). Versuche über die Keimungsbedingungen der Teleutosporen einiger Uredineen. II. Zentralbl. Bakteriol., Parasitenkd., Infektionskr. Hyg., Abt. 2, Naturwiss.: Allg. Landwirtsch. Tech. Mikrobiol. 35, 272-285.

Dietel, P. (1915). Versuche über die Keimungsbedingungen der Teleutosporen einiger Uredineen. III. Zentralbl. Bakteriol., Parasitenkd., Infektionskr. Hyg., Abt. 2, Naturwiss.: Allg. Landwirtsch. Tech. Mikrobiol. 42, 698-705.

Dietel P. (1921). Versuche über die Keimungsbedingungen der Teleutosporen einiger Uredineen. IV. Zentralbl. Bakteriol, Parasitenkd., Infektionskr. Hyg., Abt. 2, Naturwiss.: Allg. Landwirtsch. Tech. Mikrobiol. 54, 215-219.

Dinoor, A. (1962). Note on germination of crown rust teliospores and infection of Buckthorn. Can. J. Plant Sci. 42(3), 537-538.

Duncan, E. G., and Galbraith, M. H. (1972). Post-meiotic events in the Homobasidiomycetidae. Trans. Br. Mycol. Soc. 58, 387-392

Eriksson, J., and Henning, E. (1896). "Die Getreidroste, ihre Geschichte, Natur, sowie Massregeln gegen dieselben." Norstedt, Stockholm.

Fleischmann, G. (1964). Production of telia of pure races of oat crown rust for genetic studies of virulence. Ean. J. Bot. 42, 1457-1458.

Forrer, H. R. (1977). The influence of metabolites of the mycoparasite Aphanocladium album on teliospore formation of rusts. Phytopathol. Z. 88, 306-311.

Freitas, A. P. C. e (1972). Teliospores of Puccinia recondita Rob. on wheat seedlings. Actas Congr. Uniao Fitopatol. Mediterr., 3rd, 1972 pp. 127-132.

Gassner, G., and Franke, W. (1938). Untersuchungen über den Stickstoffhaushalt rostinfizierter Getreideblätter. Phytopathol. Z. 11, 517-570 
Gäumann, E. (1926). "Vergleichende Morphologie der Pilze." Fischer, Jena.

Gäumann, E. (1959). Die Rostpilze Mitteleuropas. Beitr. Kryptogamenflora Schweiz 12 $1-1407$.

Godoy, E. F., and Bruny, O. (1952). Ciclo evolution de las royas del Lino (Melampsora lini) y del Maiz (Puccinia sorghi) en la Argentina. Rev. Argent. Agron. 10, 21-34

Gold, R. E., and Mendgen, K. (1981a). Induction of teliospore germination of bean nist, Uromyces phaseoli var. typica. Phytopathology 71,219-220.

Gold, R. E., and Mendgen, K. (1981b). Induktion der Teleutosporenkeimung beim Bohnenrost (Uromyces appendiculatus var. appendiculatus). Mitt. Biol. Bundesanst. Land-Forstwirtsch., Berlin-Dahlem, 203, 318-319.

Gold, R. E., and Mendgen, K. (1983a). Activation of teliospore germination in Uromyces appendiculatus var. appendiculatus. I. The influence of aging and temperature. Phytopathol. Z., in press.

Gold, R. E., and Mendgen, K. (1983b). Activation of teliospore germination in Uromyces appendiculatus var. appendiculatus. II. The influence of light and host volatiles. Phytopathol. Z., in press.

Gottlieb, D. (1978).. "The Germination of Fungus Spores." Meadowfield Press, Durham, England.

Groth, J. V., and Mogen, B. D. (1978). Completing the life cycle of Uromyces phaseoli var. typica on bean plants. Phytopathology 68, 1674-1677.

Guyot, A. L. (1938). Les Urédinées, Tome I: Genre Uromyces. Encycl. Mycol. 8, 1-335. Guyot, A. L. (1951). Les Urédinées, Tome II: Genre Uromyces. Encycl. Mycol. 15, 1-647. Guyot, A. L. (1956). Les Urédinées, Tome III: Genre Uromyces. Encycl. Mycol. 29, $1-647$.

Harder, D. E. (1977). Electron microscopy of teliospore formation in Puccinia coronata avenae. Physiol. Plant Pathol. 10, 21-28.

Hassebrauk, K. (1936). Pilzliche Parasiten der Getreideroste. Phytopathol. Z. 9, 513-516

Hassebrauk, K. (1962). "Uredinales" (Rostpilze). In "Handbuch der Pflanzenkrankheiten. Basidiomycetes" (H. Richter, ed.), 6th ed., Vol. III, pp. 2-275. Parey, Berlin

Hennessy, C. M. R., and Sackston, W. E. (1970). Studies on sunflower rust. V. Culture of Puccinia helianthi throughout its complete life cycle on detached leaves of sunflower (Helianthus annuus). Can. f. Bot. 48, 1811-1813.

Hingorani, M. K. (1952). Factors affecting the survival ability of certain physiologic races of Puccinia graminis avenae Erikss. \&) Henn. Phytopathology 42, 526-531.

Hiratsuka, Y. (1973). The nuclear cycle and the terminology of spore states in Uredinales. Mycologia $65,432-443$.

Hooker, A. L., and Yarwood, C. E. (1966). Culture of Puccinia sorghi on detached leaves of corn and Oxalis corniculata. Phytopathology 56, 536-539.

Hughes, S. J. (1970). Ontogeny of spore forms in Uredinales. Can I Bot. 48, 2147-2157.

Jackson, A. O., and Young, H. C. (1967). Teliospore formation by Puccinia recondita $f$. sp. tritici on seedling wheat plants. Phytopathology 57, 793-794.

Johnson, T. (1930). The germination of wheat stem rust teliospores. Can. Dep. Agric Rep. Dom. Bot. pp. 51-52.

Johnson, T. (1941). Longevity of teliospores of Puccinia graminis under laboratory conditions. Phytopathology 31, 197-198.

Joshi, L. M. (1965). Studies on Puccinia hordei. II. Formation and germination of teleutospores. Indian Phytopathol. 18, 356-359.

Kapooria, R. G. (1968). Cytological studies of the germinating teliospores and basidiospores of Puccinia penniseti. Neth. I. Plant Pathol. 74, 2-7.
Kapooria, R. G. (1973). Morphological variability in teliospores of Puccinia penniseti. /. Gen. Microbiol. 77, 443-446.

Klebahn, H. (1914). Kulturversuche mir Rostpilzen. XV. Bericht. Z. Pflanzenkr. 24, 1-32. Klebahn H. (191.6) Kulturversuche mit Rostpilzen. XVI. Bericht. Z. Pflanzenkr. Gallenkd. 26, 257-277.

Klisiewicz, J. M. (197.2). Effect of host plant materials and temperature on germination of teliospores of Puccinia carthami. Phytopathology 62, 436-438.

Klisiewicz, J. M. (1973). Effect of volatile substances from safflower on germination of teliospores of Puccinia carthami. Phytopathology 63, 795.

Kohno, M., Nishimura, T., Ishizaki, H., and Kunoh, H. (1974). Cytological studies on nust fungi. I. Teliospore germination and nuclear behaviors in chrysanthemum white rust (Puccinia horiana P. Hennings). Bull. Fac. Agric., Mie Univ. 47, 1-9.

Kohno, M., Nishimura, T., Ishizaki, H., and Kunoh, H. (1975). Cytological studies on rust fungi. III. Nuclear behaviors during the process from teliospore stage through sporidial stage in two short-cycled rusts, Kuehneola japonica and Puccinia horiana. Bull. Fac. Agric., Mie Univ. 49, 21-29.

Kohno M Nishimura T Ishizaki, H., and Kunoh, H. (1977). Cytological studies on rust fungi. VII. The nuclear behavior of Gymnosporangium asiaticum Miyabe et Yamada during the stages from teliospore germination through sporidium germination. Trans. Mycol. Soc. Ipn. 18, 211-219.

Kotwal, S. N. (1970). The mode of germination of teliospores of Puccinia heterospora. Curr. Sci. 39, 285-286.

Kühn, J. (1858). "Die Krankheiten der Kulturgewächse, ihre Ursachen und ihre Verhütung". Bosselmann, Berlin.

Kulkarni, U. K. (1958). Studies in the development and cytology of Puccinia penniseti Zimm. Trans. Br. Mycol. Soc. 41, 65-73.

Lambert, E. B. (1929). The relation of weather to the development of stern rust in the Mississippi valley. Phytopathology 19, 1-71.

Lehmann, E., Kummer, H., and Dannenmann, H. (1937). "Der Schwarzrost, seine Geschichte, seine Biologie und seine Bekämpfung in Verbindung mit der Berberitzenfrage." Lehmänn, München and Berlin.

Lesovoi, M. P., Panteleev, V. K., and Parkhomenko, N. A. (1980). Metod uskorennogo polucheniya teleitospor Puccinia triticina Eriks. v. izolirovannoi kul'ture list'ev pshenitsy. Mikol. Fitopatol. 14, 79-81.

Line, R. F. (1963). Factors affecting the germination of spores of Puccinia graminis var. tritici. Diss. Abstr. 24, 23.

Lisovii, M. P., and Yabukova, I. V. (1973). Formuvannya teleitospor zbudnika buroi irzhi pshenitsi v. umovakh izol'ovanoi listkovoi kul'turi. Zakhist Rosl. 18, 76-78.

Littlefield, L. J., and Heath, M. C. (1979). "Ultrastructure of Rust Fungi." Academic Press, New York.

Lumbroso, E., Anikster, Y., Moseman, J. G., and Wahl, I. (1977). Completion of life cycles of Puccinia hordei and Uromyces scillarum on detached leaves of their hosts. Phy. topathology 67, 941-944.

McAlpine, D. (1906). "The Rusts of Australia." Brain, Melbourne.

Mandels, G. R. (1981). Compartimentation of metabolic systems in the regulation of dormancy in fungus spores. Exp. Mycol. 5, 278-29l.

Maneval, W. E. (1927). Further germination tests with teliospores of rusts. Phytopathology $17,491-493$

Melander, L. W., and Craigie, J.H. (1927). Nature of resistance of Berberis spp. to Puccinia graminis. Phytopathology 17, 95-114. 
Metzler, B. (1982). Studien über Heterobasidiomyceten (23): Basidiosporenkeimung und Infektionsvorgang beim Bimengitterrost. Phytopathol. Z. 103, 126-138.

Mims, C. W. (1977a). Fine structure of basidiospore of the cedar-apple rust fungus Gymnosporangium juniperi-virginianae. Can. I. Bot. 55, 1057-1063.

Mims, C. W. (1977b). Ultrastructure of teliospore formation in the cedar-apple rust fungus Gymnosporangium juniperi-virginianae. Can. J. Bot. 55, 2319-2329.

Mims, C. W. \{1981\}. Ultrastructure of teliospore germination and basidiospore formation in the rust fungus Gymnosporangium clavipes. Can. J. Bot. 59, 1041-1049.

Mims, C. W., and Thurston, E. L. (1979). Ultrastructure of teliospore formation in the rust fungus Puccinia podophylli. Can. J. Bot. 57, 2533-2538.

Mims, C. W. Seabury, F, and Thurston, E. L. (1975). Fine structure of teliospores of the cedar-apple rust Gymnosporangium juniperi-virginianae. Can. J. Bot. 53, 544-552

Mims, C. W., Seabury, F., and Thurston, E. L. (1976). An ultrastructural study of spermatium formation in the rust fungus Gymnosporangium juniperi-virginianae. Am. I. Bot. 63, 997-1002.

Müller, L. Y., Rijkenberg, F. H. J., and Truter, S. I. (1974). A preliminary ultrastructura study on the Uromyces appendiculatus teliospore stage. Phytophylactica 6 , 123-128.

Neuhaus, W. (1966). Über die Bedeutung des Zwischenwirtes von Puccinia sorghi Schw. Arch. Pflanzenschutz 2, 147-154

Neuhaus, W. (1969). Zur Teleutosporenkeimung von Puccinia sorghi Schw. Zentralbi. Bakteriol., Parasitenkd., Infektionskr. Hyg., Abt. 2, Naturwiss.: Allg., Landwirtsch. Tech. Mikrobiol. 123, 266-271.

Novotelnova, N. S. (1935). Some observations on the germination of the teleutospore and basidiospores of $P$. gr.f. sp. avenae and of the uredospores of $P$. triticina. Plan Prot. (Leningrad) 4, 98-106.

O'Donnell, K. L., and McLaughlin, D. J. (1981a). Ultrastructure of meiosis in the holly hock rust fungus, Puccinia malvacearum. I. Prophase I-prometaphase I. Protoplasma 108, 225-244.

O'Donnell, K. L., and McLaughlin, D. J. (1981b). Ultrastructure of meiosis in the hollyhock rust fungus, Puccinia malvacearum. II. Metaphase I-telophase I. Protoplasma $108,245-263$

O'Donnell, K. L., and McLaughlin, D. J. (1981c). Ultrastructure of meiosis in the hollyhock rust fungus, Puccinia malvacearum. III. Interphase I-interphase II. Protoplasma 108, 264.

O'Donnell, K. L., and McLaughlin, D. I. (1981d). Promycelium development in the rust Puccinia malvacearum. Mycol. Soc. Am. Newsl. 32, 43.

Pady, S. M., and Kramer, C. L. (1971). Basidiospore discharge in Gymnosporangium. Phytopathology 61, 951-953.

Pavgi, M. S. (1969). Morphology and genetics of pathogenicity of Puccinia sorghi Schw. Mycopathol. Mycol. Appl. 38, 175-187.

Pavgi, M. S. (1975). Teliospore germination and cytological aberrations in Puccinia sorghi Schw. Cytologia 40, 227-235.

Pavgi, M. S., Cooper, D. C., and Dickson, J. G. (1960). Cytology of Puccinia sorghi Mycologia 52, 608-620.

Pearson, R. C., Aldwinckle, H. S., and Seem R. C. (1977). Teliospore germination and basidiospore formation in Gymnosporangium juniperi-virginianae: A regression model of temperature and time effects. Can. I. Bot. 55, 2832-2837.

Petersen, R. H. (1974). The nust fungus life cycle Bot. Rev. 40, 453-513.

Pillai, P. K., Wilcoxson, R. D., and Raychaudhuri, S. P. (1978). Production of teliospores by some races of Puccinia graminis $f$. sp. tritici in detached wheat and barley leaves Mycopathologia 64, 101-103.

Prasada, R. (1948). Studies on the formation and germination of teliospores of rusts. Indian Phytopathol. 2, 119-126.

Rajendren, R. B. (1972). Cytology of Puccinia graminis f. sp. tritici on an artificial medium. Mycologia 64, 591-598.

Rijkenberg, F. H. J. (1977). The telial stage of Puccinia sorghi. Proc. Int. Mycol. Congr. 2nd, 1977 , pp. $1-563$

Rothman, P. G. (1974). Induction of early teliospore formation in oat rusts. Plant Dis. Rep. 58, 467-468.

Schilberszky, K. (1930). Der Berberitzenstrauch und die Schwarzrostfrage. Phytopathol. Z. $2,615-637$

Sebesta, J., and Bartos, P. (1966). Race and varietal specificity of teleutospore formation in wheat stem nust. Ochr. Rost., [N.S.] 2, 91-98.

Sibilia, C. (1930). Ricerche sulle ruggini dei cereali. 2. La germinazione delle teleutospore di P. gr. e P. triticina. Boll. Stn. Patol. Veg., Rome 10, 164-190.

Simons, M. D: $\{1954\}$. The relationship of temperature and stage of growth to the crown rust reaction of certain varieties of oats. Phytopathology 44|5|, 221-223.

Spaulding, P., and Rathbun-Gravatt, A., Jr. (1926). The influence of physical factors on the viability of sporidia of Cronartium ribicola Fischer. J. Agric. Res. (Washington, D.C.) $33,397-433$

Sussman, A. S., and Halvorson, H. O. (1966). "Spores, Their Dormancy and Germination." Harper, New York.

Takahashi, $\mathrm{H}$, and Funuta, T (1973) Observation on surface structure and behavior of Puccinia coronata Corda var. avenae Fraser et Leding, on the host plant by scanning electron microscopy. Rep. Tottori Mycol. Inst. 10, 253-272.

Takahashi, K., Yamada, M., and Takahashi, H. (1965). Teleutospore formation of lea rust, Puccinia recondita $f$. sp. tritici on young seedlings of wheat. 1. Isolate-variety relation and some characters of teleutospores. Ann. Phytopathol. Soc. Ipn. 30, $54-61$.

Takahashi, K., Tanaka, T:, Yamada, M., and Takahashi, H. (1973). On the relationship between physiologic races and alternate hosts of wheat stern rust, Puccinia graminis Pers. f. sp. tritici in Japan. Rep. Tottori Mycol. Inst. 10, 273-282.

Thiel, A. F., and Weiss, F. (1920). The effect of citric acid on the germination of the teliospores of $P$. gr. tr. Phytopathology 10, 448-452.

Tulasne, L. R., and Tulasne, C. (1847). Mémoire sur les Ustilaginées comparées aux Urédinées. Ann. Sci. Nat. Bot. Biol. Veg. 3, 12-126.

Turian H., and Hohl, H. R., eds. (1981). "The Fungal Spore." Academic Press, New York.

Ullrich, J. (1977). Die mitteleuropäischen Rostpilze der Futter- und Rasengräser. Mitt. Biol. Bundesanst. Land-Forstwirtsch., Berlin-Dahlem 175, 1-71.

Urban, Z. (1969). Die Grasrostpilze Mitteleuropas mit besonderer Berücksichtigung der Tschechoslowakei. Rozpr. Cesk. Akad. Ved. Rada Mat. Prir. Ved. 79, 3-104.

Van Arsdel, E. P. (1967). The nocturnal diffusion and transport of spores. Phytopathology $57,1221-1229$

Van der Wal, A. F. (1970). Interaction between Puccinia recondita f. sp. triticina and Septoria nodorum on wheat, and its effects on yield. Neth. I. Plant Pathol. 76, $261-263$.

von Brandenburger, W., and Schwinn, F. J. (1971). Über Oberflächenfeinstrukturen von Rostsporen. Eine rasterelektronenmikroskopische Untersuchung. Arch. Mikrobiol. $78,158-165$. 
Ward, H. M. (1888). Illustrations of the structure and life-history of $P$. gr., the fungus causing the rust of wheat. Ann. Bot. (London) 2, 217-222.

Waterhouse W. L (1921). Studies in the physiology of parasitism. VII. Infection of Berberis vulgaris by sporidia of P. gr. Ann. Bot. (London) 35, 557-564.

Waters, C. W. (1928). The concrol of teliospore and urediniospore formation by experimental methods. Phytopathology 18, 157-213.

Wells, K., and Wells, E. K, eds. (1982). "Basidium and Basidiocarp." Springer-Verlag, New York/Heidelberg.

Wenzler, H., and Brambl, R. \{1981\}. Mitochondrial biogenesis during fungal spore germination. I. Biol. Chem. 14, 7166-7172.
miter, $H_{\text {. }}$ and Brambl, R. $\{1981\}$. Mitoch

Yamada, M., Takahashi, K., Takahashi, H., and Tanaka, T. (1973). Studies on alternate host, Thalictrum thunbergii DC., as an origin of physiologic races of wheat leaf rust, Puccinia recondita Roberge ex Desm. f. sp. tritici in Japan. Rep. Tottori Mycol. Inst. $10,283-302$.

Yaniv, Z, Kenneth, R. G., and Miura, J. (1979). Teliospore formation in Puccinia graminis f sp. tritici grown in axenic culture, induced by the fungus Aphanocladium album. Physiol. Plant Pathol. 14, 153-156.

Zimmer, D. E., and Schafer, J. F. (1960). Variability of telial formation of Puccinia coronata. Proc. Indiana Acad. Sci. 70, 91-95. 